\title{
Kjell Östberg, I takt med tiden. Olof Palme 1927-1969.(Stockholm, Leopard, 2008, pp. 427)
}

\section{by Monica Quirico}

This volume is the first part of the monumental work devoted to the famous Swedish Prime Minister by Kjell Östberg, Research Leader at the Institute of Contemporary History at Söderntörn University in Stockholm (a second volume is currently forthcoming). The title, Behind the times, is very well-conceived with respect to the author's methodology and to what was, according to Östberg, Palme's distinctive character. The book is remarkable as it is not only a detailed biography, showing impressive archival research, but also an exhaustive reconstruction of Swedish political and intellectual life in the 2oth century. As to Palme's peculiarity, Östberg stresses the Prime Minister's talent in getting the Zeitgeist straight away, with the isolated but crucial exception of 1968.

The first part of the volume (Barndom och ungdom) follows Palme's childhood and youth. The Palmes were typical representatives of the upper class, of which Östberg appropriately recalls the dark side too (e.g. racism and Nazi likings). Olof's choice to join Social Democracy was at odds with his social background, yet it was not a scandal for his family, from which he inherited values such as sensitiveness for the issue of nationality, anti-Communism, and a keen eye for international affairs.

Palme's education followed the typical path of his class: a university degree (in Law), military service as an Army officer, overseas sojourns. The first one, in the USA (1947), was a turning point in Palme's life, kindling in him a deep attraction for that country. Important as well were his journeys to Eastern Europe (1949), which strengthened his rejection of Communism, and Asia (1953), which enabled him to experience the problems of the Third World.

It was then that Palme approached politics, first in the International Student Movement (the pro-USA wing), successively, in 1951, joining the Social Democratic Party (SAP). He thus met Tage Erlander, party chairman and Swedish premier as of 1946 , becoming soon the most prominent member of his staff.

The second part of the book (5o-tal) describes SAP's impasse in the early 1950 os and the role played by Erlander and Palme in providing it with a renewed ideology, i.e. the "strong State", suitable to an impressive growth of the public sector and Welfare State, following an universalistic model. Such a development (1950s-1960s), proved to be an extremely effective way to involve the middle class in the "social block" supporting Social Democracy. In the 1930s, SAP had introduced Keynesianism before Keynes; in the 1950s, it anticipated Galbraith's ideas: Östberg argues that economic liberalism has always been one of the main ideological sources for Swedish Social Democracy. 
The author follows Palme's political career-included “the secret Palme", i.e. his role at the Ministry of Defence-and identifies international solidarity and equality as core-values of his political platform in the 1950s. Not surprisingly, he became one of the most qualified party leaders to grasp what was changing in the shift from the 1950 to the 1960s, thanks also to his good relationships with radical intellectuals.

To the decade of radicalization is related the third part of the volume (6o-tal). In 1963, Palme was appointed as minister without portfolio and two years later as minister of communications. Östberg shows that he succeeded in including equality and solidarity to the Third World in a Social Democratic Weltanschauung mixing the pursuit of ideals with pragmatism; a skill which favoured his reputation both as an ideologist and as a renewer. Consistently, the charge to hold a dialogue with the New Left fell onto him. At first, Palme did not disappoint the expectations placed upon him: the words he used to condemn USA intervention in Vietnam caused a sensation, driving many, both at home and in Washington- Nixon was not polite at all with him-to wonder whether Sweden was giving up her celebrated neutrality. The diplomatic relations between the two countries remained troublesome for a decade, though not so the business ones, which were always good. Östberg wonders why Palme, who had never belonged to the party left wing, took such a harsh position on the Vietnam war. The answer he gives is not one-sided: Östberg underlines that Palme's spoken radicalism was not followed by radical peace proposals; hence the left-wing criticism that foreign policy was being used by the young minister to compete with the New Left. At the same time, Östberg insists that one does not have to forget Palme's early interest in Third World's rights, and furthermore his will to assign to Sweden an international role.

In 1967 Palme was appointed as minister of education and culture; once again, he showed his talent in reform policies: his two main achievements were the foundation of the Council for Cultural Affairs, intended to improve equality in society, and the study allowance system, which became a cornerstone of the Swedish universalistic Welfare State.

To 1968 revolutionary tendencies Palme opposed Swedish successful reformism, which in his view-questioned by Östberg-could be a model for Third World countries too. Palme did not refuse to face the student movement; when Stockholm University was occupied, in May, he accepted to meet the students in the middle of the night. It was definitely a brave act, but, according to Östberg's, since then he seemed to lose touch with radical movements and intellectuals, as his cold-War mentality prevented him from understanding the novelty that they represented, which was not referable to the old dichotomy Communism vs. Anti-communism. Not surprisingly, when the 1969 congress-characterized by the equality issue-appointed him as new chairman, the prevailing reaction from the bourgeois media was positive: no frightening change was to be expected.

Palme became soon very popular in the international press, the symbol of a new 
generation of politicians, and thanks to him the attention paid to the Swedish model increased all over the world. The crisis in the early 1970s-thus Östberg anticipates the content of his second volume-would then put to a test Palme's faith in the endless opportunities of reformism.

Monica Quirico, Ph.D. in History of Political Ideas, Political Institutions and Political Philosophy ("La Sapienza" University of Rome), currently works at the Department of Political Studies of the University of Turin. Her research has dealt with Marxism and the history of liberalism (Italian and, above all, British) and, in recent years, with Swedish history and society. In addition to several essays in Italian scholarly journals, she has published two books (in Italian): Socialism in the Face of Reality. The Swedish Model 1990-2006, Roma, Editori Riuniti, 2007 and Collectivism and Totalitarianism. Hayek and Michael Polanyi (1930-1950), Milan, FrancoAngeli, 2004. 